\title{
Moroccan Facebook Visual Narratives and Cultural Production
}

\author{
Driss Faddouli* \\ Department of English, Ibn Tofail University, Morocco \\ * Corresponding author email: drissfaddouli@hotmail.fr \\ Received: 22 January 2019 / Revised: 25 February 2019 / Accepted: 20 March 2019 / Published: 20 March 2019

\begin{abstract}
A BS T RA C T
In this paper, I argue that the creation and circulation of the visual narratives within Facebook groups by Moroccan Facebookers largely entail and substantiate a stronger process of cultural production that has its own logic and praxis. I argue that this process of cultural production has two major facets: an aestheticization of everyday life and promulgation of specific modes of consciousness. Through the aestheticization of everyday life, I posit that Moroccan youth's acts of cultural production increasingly blur the formal boundaries between the Internet, art, and popular culture; an aspect which fundamentally empowers their creative online input. Through the promulgation of specific modes of consciousness, I argue that the visual narratives attempt to develop and enhance the cultural sensibilities which better champion their perceptions and stances. Taken together, I claim that these major manifestations of the process of cultural production, while being deeply wedded to the Gramscian and Foucauldian perception of power dynamics, set the tone for an underlying struggle over power and meaning-making in the Moroccan society, thus seeking to intervene and exploit the gaps and contradictions in these power dynamics in society.
\end{abstract}

Keywords: Moroccan Facebookers; visual narratives; cultural production; politics; popular culture.

\section{Introduction}

Most Moroccan Facebookers do demonstrate a measure of critical reflexivity. The intense grassroots' manipulation of popular events, mainstream images, commercial ads, TV series, and home-made videos is but a strong testimony of this critical reflexivity displayed by these Moroccan Facebookers. Their creative forms, practices, and uses are part and parcel of their daily networked experiences. Moroccan Facebookers are highly active on social networking websites. Massive numbers of active Moroccans have personal profiles on Facebook, produce or consume different videos on YouTube, and have even started to interact on Twitter. Within these online spaces, they continuously appear to generate, post, and circulate plenty of online content. Its intensity and quality attests to the assumption that Moroccan youth are highly engaged with the national as well as the global issues. They are deeply attached to most of the issues, debates, and controversies relevant to their local, national and even global contexts. On a daily basis, they comment, debate, post, and circulate images, cartoons, videos, and hyperlinks. Most of these appear to be widely laden with revealing and insightful symbolic and performative cues. Oftentimes, the online content circulated within the variety of Moroccan Facebook groups reveals that there are signs of online discursive and aesthetic practices that are indicative of the depths of Moroccan Facebookers' intellectual and critical prospects. They show that their interventions and articulations rigorously contribute to enhancing a number of discursive and aesthetic forms, which in turn, attest to the presence of online oppositional discourses, subversive symbols, and even minor public spheres. More importantly, they could be taken to represent a 
singular form of civic and political engagement conditioned by these Moroccan Facebookers' aspirations and desires.

Interestingly, within Moroccan Facebook spaces huge numbers of Moroccan Facebookers seem to cherish the tendency to express themselves visually in engaging with various sociocultural and political controversies inflicting Morocco. They post and share visuals of versatile content and form; visuals that some of which would occasionally bear on the private lives of these young people, while others would often reflect an acute sensitivity to the general public matters of the nation all in such funny and amusing ways. Putting this tendency in perspective, it becomes clear now to describe these online users, borrowing Nicholas Mirzoeff's (2002) term, as "visual subjects" (p. 10). Since they widely tend to audio-visually express themselves to engage with a variety of sociocultural issues of concern, Moroccan Facebookers, in this sense, demonstrate an online agency that is audio-visually grounded; it is particularly reflected in the production of various image-macros (an image macro is basically an image onto which a text has been added), comics, cartoons, and videos articulating their perceptions and viewpoints. Moroccan Facebookers capitalize on the importance of the visual in producing meanings, sustaining viewpoints, dismantling counter ideologies, and laying bare power relationships.

Thus, Moroccan Facebookers are fundamentally visual subjects, for they unceasingly draw on their imaginative repertoires, cultural legacies, and daily experiences to flood online Moroccan spaces with visually important artifacts that, in the words of Rogoff, retain multi-layered and free signifiers, remake the world in the shape of these youth's fantasies and desires, or that narrate the stories which they carry within themselves (2002, p. 26). In this regard, Moroccan Facebookers' stronger inclination to engage with the visual message can be conceived as communicating a need to provide a visual rewriting of Moroccan culture, one that exists at the intersection of both objectivity and subjectivity and serves to translate their concerns, mirror their aspirations as well as to animate their life journeys.

\section{Moroccan Facebookers and Cultural Consumption}

To begin with, Moroccan Facebookers' daily acts of cultural consumption constitute the threshold to understanding the foundational aspects of this significant process of cultural production in operation. For Moroccan Facebookers, everyday life constitutes a rich landmine from which they can draw their initial inspiration for entertainment and creative action. As such, numerous sites of interests or concerns initially crop up from the quotidian events, stories, jokes, statements, images, and fantasies animating Moroccan popular culture. Consequently, Moroccan Facebookers increasingly capitalize on these sociocultural and political events, deploying them as their entry-point to enact a host of shareable and enjoyable networked experiences. For instance, stories of Moroccan celebrities caught in noble or vicious acts are immediately rendered into image-macros often with satirical messages. Videos of ordinary people performing legendary actions are sometimes turned into video mashups meant for social commentary, when jokes or stereotypical anecdotes about certain social groups or funny political statements are usually deployed into forms of political cartoons or comics. The importance of this cultural resource of action lies in its alluring power to implicate Moroccan Facebookers into a potentially transformative praxis, enabling them to develop communicative competences, formulate candid personal viewpoints, normative conceptions, and feel a myriad of desires (Gardiner, 2000, p. 2). More importantly, it offers them the ability to construct what Bakhtin calls the "answerably performed act- a synthetic or architectonic activity which brings together the sense and the fact, the universal and the individual, the real and the ideal" (Bakhtin, 1993, p. 23). It offers them the opportunity to imprint their personal signature on the various expressive acts. Thus, everyday life in this sense becomes a decisive tool in the hands of these young people.

To appreciate the deeper implicative aspects of these acts of cultural consumption in relation to cultural production, it would be of paramount importance to consider both Michael de Certeau's and Michel Foucault's theorizations of power dynamics in society. On the one hand, de Certeau perceives cultural consumption as being basically tactical in nature, eschewing the panoptical gaze of the bureaucratic power. He theorizes it as a form of "poesies" tremendously conditioned by the cultural consumer's sense of social 
Driss Faddouli, Adv. J Social Sci.; Vol. 5 Issue 1, pp: 45-51, 2019

intelligence and critical alertness. He claims that it represents "unofficial, marginal practices, and clandestine forms taken by the dispersed, tactical, and makeshift creativity of groups or individuals already caught in the nets of discipline" (Certeau, 1984, p. xiv). Indispensable to these forms of cultural consumption emerges the role of the consumer. Contrary to the prevalent assumptions characterizing the consumer as a docile and manipulated subject, de Certeau (1984) contends that the latter tactically manipulates the cultural commodities one receives. He asserts that consumers always seek to appropriate, use, and attribute meaning to cultural artifacts in a myriad of unexpected and surprising ways. They often attempt to impose a form of transcription on these cultural commodities that "reflects non-formalized practices transforming the original symbolic and physical materials" (as cited in Gardiner, 2000, p. 170) contained in the commodities. Certeau (1984) defines consumption as follows:

In reality, a rationalized, expansionist, centralized, spectacular and clamorous production is confronted by an entirely different kind of production, called 'consumption' and characterized by its ruses, fragmentation (the result of the circumstances), its poaching, its clandestine nature, its tireless but quiet activity, in short by its quasi-invisibility, since it shows itself not in its own products but in an art of using those imposed on it. (p. 31)

Thus, de Certeau perceives cultural consumption as being always tactical in nature, intending to subvert and alter the dominant cultural rules, representations, rituals, and hegemonies. It often capitalizes on what Michael Sheringham (2006) defines as the temporality of the incident or the event whereby it manifests itself in the timely intervention which profits from circumstances or the swiftness of action (p. 216). In this respect, tactics represent significant practices embodying this cultural consumption. De Certeau (1984) claims that the space of the tactics is the space of the other (that is, the space of the dominant). Tactics are composed with the vocabularies of the established languages (those of television, newspapers, supermarkets, or museum sequences). Yet, they trace out the ruses of other interests and desires that are neither determined nor captured by the systems in which they develop (Certeau, 1984, p. xvii). They find outlets in the types of "the improvisation and expectation of meanings inferred from a few words, the ruses of pleasure and appropriation, the poaching on things, the metaphor or arrangement of the interventions, the invention of the memory, or the product of silent histories" (Certeau, 1984, p. xxi).

On the other hand, Michel Foucault's account of power relationships, particularly his conceptualization of the intricate ways they dominate the minds of individuals and groups in society, is necessary here. Foucault perceives that power relationships are inscribed in society, mostly through implicit, less obvious ways. He states that power relations sustain themselves not only through the explicit state apparatuses (the army or the judiciary) but also through the "microphysics of power" that infiltrate the day-to-day existence of people (as cited in Gardiner, 2000, p. 167). For him, the dominant groups, institutions, or states always seek to normalize individuals and groups by keeping a stronger bureaucratic system that monopolizes the resources and knowledge to control and condition the individual's behavior.

As such, both de Certeau and Foucault offer here an insightful theoretical and conceptual bearing on how power relationships sustain in the society and how they can be subverted. In particular, they help situate our discussion of Moroccan Facebookers' acts of cultural consumption within this theoretical framework, thereby illuminating their major aspects of cultural production. Such a theoretical bearing, in other words, would enable us to examine the underlying dynamics of this cultural production and how they set the claim for the creation and the dissemination of certain meanings, representations, and narratives that intersect and crisscross with the mainstream articulations, assertions, and discourses. In this regard, Moroccan Facebookers' cultural production can best be conceptualized from four major encompassing aspects: the aestheticization of everyday life, the dissemination of certain modes of consciousness, the inscription of certain structures of feelings, and the institutionalization of new media forms.

\section{Aspects of Cultural Production}

In line with this, the aestheticization of everyday life represents the first significant manifestation of this process of cultural production. Moroccan youth's acts of cultural production increasingly tend to blur the 
Moroccan Facebook Visual Narratives and Cultural Production

formal boundaries between the Internet, art, and popular culture; an aspect which fundamentally empowers their creative online input. They demonstrate a "general stylistic promiscuity and playful mixing of codes" (Mike Featherstone, 2007, p. 64) that are mostly observed in their strong critical and thematic interventions into the wider sociocultural and political contexts of the Moroccan society. In this respect, the visual narratives under study incorporate a wider diversity of issues and themes motivating Moroccan youth to take action. For instance, social issues are widely broached upon in these narratives. The social concerns such as the recent rising prices, poverty, unemployment, homelessness, misery, richness, and luxury voiced in the cartoons and comics all translate the Moroccan Facebookers' acute sense of social sensitivity and aspiration to bring about change. The social problematic is highly staged and consequently gives shape to the several experiences of the jolts and the shocks in these visual narratives. Likewise, the promiscuously "vivid presentness" with which the social issues are encoded can be said to obliterate the difference between the real and the unreal in the images, thereby leaving much room for establishing a sense of bewildering immersion on the part of the viewer. The Moroccan Facebookers' aestheticization of the social grievances works to bring these issues to central stage. Similarly, political issues also have a considerable place in these visual narratives. Evaluating the governmental results, criticizing the Prime Minister, making fun of the state ministers, exposing corrupt political decisions or behavior, and arguing for or against the merit of some public institutions reveals how politics is now deeply enmeshed in the minds and hearts of the young Moroccan Facebookers. They affirm that politics is no longer monopolized by the few elites and politicians. The cartoons and comics pertinent to the political concerns can be said to "break down the ordered chain of the signifiers" (Featherstone, 2007, p. 64) in an attempt to negate and subvert the formal discursive elements. As such, alternative political voices are consequently given an outlet and empowered to rewrite and underscore the political power struggle in Morocco. Thus, the increasing dismantling and flow of free signs in the Moroccan political context enables the visual narratives in concern to rework and redefine alternative political needs and demands on the part of the Moroccan Facebookers. Borrowing Adorno's words, the visual narratives ultimately give prominence to the "secondary use-value" inherent in the cultural elements, or what Baudrillard calls "sign-values," that direct the viewer to the alternative political desires and demands in the images (as cited in Mike Featherstone, 2007, p. 66). Moreover, the cultural controversies articulated in the visual narratives such as religious fanaticism, women's rights, language policy, entertainment or leisure, and body politics all foreground the immense critical cultural output performed by these young people. They demonstrate, in Jameson's words, the "loss of a sense of history and the fragmentation of time" shaped into the form of "perpetual presents [of] multiphrenic intensities" (Featherstone, 2007, p. 64). The personal expressions displayed in the cartoons and comics in particular retain evershifting perspectives enmeshed into the dialectics of allegiances and subversions between the traditional and the modern or the secular values. They give rise to a dichotomous relationship between the new and the traditional cultural experiences revealed in the form of many intriguing modes of signification (Featherstone, 2007, p. 64).

As regards the second dimension of the Moroccan Facebookers' act of cultural production, the visual narratives attempt to promulgate the modes of consciousness that better champion their perceptions and stances. Acute social and political commentary, satire, ridicule, mockery, and emphasis, to mention but a few, often shape the modes of perception informing the cartoons, comics, and the images. The visual narratives addressing social grievances, for instance, express fierce social criticism of the Moroccan authorities held responsible for the misery of numerous citizens. Blame and doubt of the state officials are also two representative modes of consciousness infiltrating these visual forms. Satire and ridicule also go deep into the representation of the government or the cultural issues in Morocco. In addition, the articulation of these modes of consciousness is increasingly constituted and established among Moroccan online users to the extent that it sustains their quotidian aesthetic practices. More importantly, the institutionalization of these modes of consciousness attempts to stage the "changing interdependencies and struggles between figurations" of the Moroccan citizens. It historicizes the emerging "cognitive styles and 
Driss Faddouli, Adv.J Social Sci.; Vol. 5 Issue 1, pp: 45-51, 2019

modes of perception" that are now dominant among and characteristic of the Moroccan youth (Featherstone, 2007, p. 64).

The institutionalization of certain structures of feeling represents the third aspect of this process of cultural production. The visual narratives are populated with feelings of grievance, discontent, empathy, support, and passion to take action. They reflect a great sense of urgency and discontent on the part of the young Moroccan Facebookers. Although most of these visual narratives fail to articulate better alternatives for the ills of the society, they nonetheless face up to what they believe to be aspects of backwardness and underdevelopment in the Moroccan society, mobilizing and investing in the power of desire. They implicate the viewers into a host of emotionally charged experiences that call for "a decontrol of emotions [and] an opening up to the full range of sensations available" (Featherstone, 2007, p.70) in these experiences. As such, the visual narratives capitalize on the alternative structures of feelings which trigger the viewer, in Lash's words (1988), to de-differentiate and de-distantiate from the object of representation (as cited in Featherstone, 2007, p. 70).

The emerging forms of the online content constitute the fourth aspect of Moroccan youth's cultural production. Moroccan youth creates hybrid aesthetic forms. Various cartoons, comics, image-macros, viral video mashups, statements, and quotes harbor these youth's ideas, views, and feelings and populate the Moroccan networked spaces. They easily lend themselves to the Moroccan youth and offer them opportunities to experience audacious roles, cross new boundaries, and acquire sophisticated skills. The significant aspect about these remix forms is that they entail a "combinatory logic" transforming them into what Scott Church (2015) defines as a "communicative practice [having] rhetorical dimensions, persuasive possibilities, and cultural implications" (as cited in Eduardo Navas \& et al., p. 43). This logic illuminates and paves the way for the Moroccan youth to develop a variety of new remix forms that entail their ideological viewpoints and stances. They also foreground the collective authorship often involved in the creation of the cartoons, comics, and the images. As Stefan Sonvilla Weiss (2015) describes, they demonstrate "the heterogeneity and excitement of a variety of stakeholders whose ideas are brought out in synchronous, asynchronous, and serial forms of collaboration" (p. 57). Vito Campanelli (2015) further elaborates on this point as follows:

Today most of the information is not produced by individuals but by dialogic groups and, moreover, the statute of the work has been radically changed by the technical possibilities of infinitely reproducing and editing each work. In the telematic society envisioned by Flusser, all information is synthesized through intersubjective conversations and its purpose is to be modified by the receivers and put back into the flow as new information. (p. 70)

As such, these hybrid visual forms can be said to retain "a constitutive element that disrupts the moral and shared codes" (Campanelli, 2015, p. 72) of the Moroccan dominant groups and cultural systems of thought. They give access to a repertoire of endless practices and strategies for the benefit of the Moroccan online users.

Taken together, these major manifestations of the process of cultural production, culminated in the creation of the visual narratives under study, set the tone for an underlying struggle over power and meaning-making in the society. They are deeply wedded to the Gramscian and Foucauldian perception of power dynamics. As the Moroccan Facebookers' acts of cultural production obviously come in response to the dominant power relations in the society, they nonetheless seek to intervene and exploit the gaps and contradictions in these power dynamics in society. They resist and challenge the power to fix and normalize certain meanings and structures. Taking cue from Eric Louw (2001), they attempt to enact and bring about "relational shifts or power shifts" in meaning structures in the Moroccan society (p. 12). Importantly, the challenge to these structuring qualities of power relationships indeed comes in the form of stronger subversions and disarticulations of the meanings articulated by the state elites, the mainstream institutions, and the dominant cultural systems.

The state elites and the mainstream institutions play crucial roles in generating, circulating, and sustaining the dominant meanings and values in the society. On the one hand, professionalized meaning-makers play 
a significant role in advocating the claims of the dominant groups in the society. Acting as both regulators and generators of meaning in circulation, the state intellectuals exercise a significant influence in society, favoring certain interpretations and perceptions at the expense of others. They circulate these in the form of ideas, assumptions, convictions, and cultural commodities. At stake, as Gramsci (1971) asserts, is the intellectual work of these intellectuals because it all too often becomes subservient to the dominant power relationships in the society and to the organizational sites for which it is recruited. Thus, the state intellectuals may serve to cater for the hegemonic needs and interests in the society. On the other hand, the mainstream institutions inevitably incorporate and harbor the intellectual work of the state elites. They attempt to foster and institutionalize the dominant meanings, assumptions, beliefs, and convictions in the society by channeling these into mainstream media corporations and outlets. In this regard, the mainstream TV channels and the newspapers play an important role in this context. The flow of communication and meaning circulation is what is at stake here: it becomes top-down and unidirectional, thus walling off ordinary citizens from engaging in the process of meaning-making. Therefore, these institutions, in the words of Cohen (1963), contribute to "setting social agendas and instigating people on what to think about" (p. 13).

In line with this, Moroccan Facebookers' acts of subversion and disarticulation come in large part to dismantle these dynamics of power set by these intellectuals and institutions. They enact a struggle over meaning that is inscribed and bred within an emerging counterhegemony that seeks to achieve sociocultural legitimacy. Echoing Hall (1980), they renegotiate the meanings generated by these power holders.

\section{Conclusion}

Moroccan Facebookers' acts of cultural production indeed can be largely conceived as occupying a major stage in the more general, more transformative act of writing or narrating the Moroccan nation. They give rise to a site of conceptual ambivalence that reveals their awareness of the central role of the visual forms in the process of cultural signification and, particularly, their productive possibilities of challenging the image of cultural authority. Moroccan Facebookers' acts of cultural production bring to task the cultural authority because the latter is "caught, uncertainly, in the act of 'composing' its powerful image". In fact, the discussion of the process of cultural production fostered by the Moroccan online users brings us to consider another significant dimension of the visual narratives under study. It points to one of the most important implicative aspects underlying the strategic creation and promulgation of the visual forms. By way of generating an increasingly creative visual content within the networked spaces, especially Facebook, Moroccan youth seeks to inscribe and underscore a stronger online presence that emphasizes their individual subjectivities and collective identities.

\section{How to Cite this Article:}

Faddouli, D. (2019). Moroccan Facebook Visual Narratives and Cultural Production. Advanced Journal of Social Science, 5(1), 45-51. DOI : $10.21467 /$ ajss.5.1.45-51

\section{References}

AL Jarida Rasmiya, October $3^{\text {rd }}, 2016,6505$.

Bhabha, H. (Ed.). (1990). Nation and narration. London and New York, USA: Routledge. View

Campanelli, V. (2015). Toward a remix culture: An existential perspective. In Navas, E. Gallagher, O. \& T. Burrough, The routledge companion to remix studies $\left(1^{\text {st }} \mathrm{Ed}\right.$.). New York, USA: Routledge.

Certeau, M. de. (1984). The practice of everyday life, S. Rendall (trans.), Berkeley, USA: The University of California Press. View

Cohen, B.C. (1963). The Press and foreign policy. Princeton, NJ, USA: Princeton University Press. View

Church, S. (2015). A rhetoric of remix. In Navas, E. Gallagher, O. \& T. Burrough, The Routledge companion to remix studies (1 $1^{\text {st }}$ ed.). New York, USA: Routledge.

Featherstone, M. (2007). Consumer culture and postmodernism ( $2^{\text {nd }}$ ed.). London, England: Sage Publications. View

Hall, S. (1980). Encoding/ decoding. In S. Hall (Ed.), Culture, media, language: Working papers in cultural studies, 1972-79 (pp.128-138). London: Hutchinson. View

Gardiner, M. (2000). Critiques of everyday life. London, England: Routledge.

Gramsci, A. (1971). Selections from the prison notebooks. London, England: Lawrence \& Wishart. View

Mirzoeff, N. (Ed.). (2012). The visual culture reader $\left(2^{\text {nd }}\right.$ Ed.). London, England: Routledge. 
Driss Faddouli, Adv.J Social Sci.; Vol. 5 Issue 1, pp: 45-51, 2019

Louw, E. (2001). The media and cultural production. London, England: Sage Publications.

Sheringham, M. (2006). Everyday life: Theories and practices from Surrealism to the present. Oxford, England: Oxford University Press. View

Weiss, S. S. (2015). Good artists copy, great artists steal: Reflections on cut-copy-paste culture. In Navas, E. Gallagher, O. \& T. Burrough, The routledge companion to remix studies $\left(1^{\text {st }}\right.$ Ed.). New York, USA: Routledge.

Publish your research article in AIJR journals-

$\checkmark \quad$ Online Submission and Tracking

$\checkmark$ Peer-Reviewed

$\checkmark \quad$ Rapid decision

$\checkmark \quad$ Immediate Publication after acceptance

$\checkmark \quad$ Articles freely available online

Retain full copyright of your article.

Submit your article at journals.aijr.in
Publish your books with AIJR publisher-

$\checkmark \quad$ Publish with ISBN and DOI.

$\checkmark \quad$ Publish Thesis/Dissertation as Monograph.

$\checkmark$ Publish Book Monograph.

$\checkmark \quad$ Publish Edited Volume/ Book.

$\checkmark \quad$ Publish Conference Proceedings

$\checkmark \quad$ Retain full copyright of your books.

Submit your manuscript at books.aijr.org 